\title{
Evaluasi Penggunaan Learning Management System Sebagai Alat Bantu Pembelajaran Matematika Sekolah Dasar
}

\author{
http://dx.doi.org/10.28932/jutisi.v7i3.3977 \\ Riwayat Artikel \\ Received: 16 September 2021 | Final Revision: 25 November 2021 | Accepted: 26 November 2021 \\ Kenny Jingga ${ }^{\bigotimes \# 1}$, Bernard Renaldy Suteja ${ }^{* 2}$, Mewati Ayub ${ }^{* 3}$ \\ * Computer Science Department, School of Computer Science, Bina Nusantara University \\ Jl. Kebon Jeruk Raya No. 27, Jakarta Barat 11480, Daerah Khusus Ibukota Jakarta \\ ${ }^{1}$ kenny.jingga@binus.ac.id \\ * Program Studi Magister Ilmu Komputer, Universitas Kristen Maranatha \\ Jl. Prof. drg. Surya Sumantri No. 65, Bandung 40164, Jawa Barat \\ 2bernard.rseit.maranatha.edu \\ ${ }^{3}$ mewati.ayub@it.maranatha.edu
}

\begin{abstract}
Teaching and learning activities need to be interactive to increase children's interest in learning. With the utilization of technology, there are so many learning tools had been made. One of them is Moodle. Moodle is a learning management system (LMS) application to support learning activity on electronic based (e-learning). The purpose of this research is to implement Moodle as LMS for mathematics learning on primary school children. By using Moodle, the lessons are delivered interactively for children to learn. This research will find out the influence of using this application towards the test score before and after using the application. T-Test analysis will be applied to analyze the differences. Besides analyzing the test score, questionnaires for the children who test the application will be given to know the effect of using the application for them. Based on the evaluation result using T-Test analysis, there were not any significant differences, but there were enhancements in average, highest, and lowest scores, along with the decrease in standard deviation. The result of correlation coefficient calculation between exercise frequency and quiz result was $\mathbf{0 . 2 1 6 2}$, which meant that the correlation was weak or almost no correlation. Based on the questionnaire result, this application is considered helping children in understanding the subject.
\end{abstract}

Keywords—e-learning; learning management system; mathematics; Moodle; t-test.

\section{Pendahuluan}

Semakin berkembangnya zaman, maka semakin berkembang juga teknologi. Perkembangan teknologi yang sangat pesat ini turut memberikan kemudahan bagi manusia, khususnya dalam dunia pendidikan. Banyak sekolah-sekolah yang memanfaatkan teknologi komputer untuk kegiatan pembelajaran. Di Indonesia sendiri, ujian nasional telah menggunakan pemeriksaan melalui sistem berbasis komputer [1].

Teknologi pendukung pembelajaran yang telah banyak digunakan adalah learning management system (LMS) [2]. LMS dapat diakses melalui internet, sehingga kegiatan pembelajaran dapat dilakukan tanpa adanya pertemuan fisik. Hal tersebut dapat memudahkan pelajar untuk mempelajari materi yang tersedia terlebih dahulu, sehingga pelajar dapat lebih cepat memahami materi tersebut. LMS juga memberikan tampilan yang interaktif, sehingga dapat meningkatkan minat belajar para pelajar, khususnya anak-anak.

Pengenalan teknologi kepada anak-anak sejak dini dengan pengawasan yang tepat dapat memberikan dampak positif untuk anak-anak itu sendiri, Tidak dapat dipungkiri, kemajuan teknologi yang sangat pesat dapat menjadi hal yang positif sekaligus negatif untuk perkembangan anak-anak. Dengan memperkenalkan LMS pada anak-anak, mereka akan mendapatkan langkah awal yang positif dalam memasuki dunia teknologi.

Bagi kebanyakan anak-anak, mata pelajaran matematika adalah mata pelajaran yang dianggap sulit untuk dipahami [3]. Matematika sendiri merupakan mata pelajaran yang dapat melatih kemampuan logika anak-anak dengan berhitung. Untuk 
pembelajaran yang akan dilakukan melalui LMS ini, materi mata pelajaran matematika akan dimasukkan sebagai bahan pengujian.

Learning management system adalah sebuah aplikasi perangkat lunak untuk kegiatan e-learning yang dapat diakses melalui internet [4]. LMS banyak digunakan untuk memenuhi kebutuhan dunia pendidikan. Sekolah-sekolah sudah mulai menerapkan LMS sebagai media pembelajaran dan interaksi antara guru dan siswa. Penggunaan LMS dinilai dapat meningkatkan minat belajar siswa dan memperkenalkan teknologi pada siswa. Selain itu, penggunaan LMS juga dapat meringankan pekerjaan guru, seperti memberikan tugas-tugas rumah atau kuis. LMS dapat membantu guru dalam memberikan penilaian atas tugas-tugas ataupun kuis siswa [2], [5]. Penggunaan LMS sudah mulai digunakan sejak tingkat sekolah dasar. Hal ini dilakukan untuk membiasakan anak-anak sejak kecil menggunakan teknologi sebagai media untuk kegiatan yang positif. Interaksi-interaksi yang ada di dalam LMS juga dapat menarik perhatian anak-anak untuk menggunakan alat tersebut. Sehingga, secara tidak langsung anak-anak akan mau memperhatikan materi yang disajikan dalam LMS tersebut.

LMS sebagai alat bantu pembelajaran dalam penerapannya memiliki beberapa keunggulan dan juga kelemahan [6]. Keunggulan LMS sebagai alat bantu pembelajaran adalah efisiensi biaya, efektivitas pembelajaran, fleksibilitas waktu, fleksibilitas tempat, dan fleksibilitas kecepatan pembelajaran. Selain keunggulan di atas, kelemahan dari LMS adalah terkait masalah kesiapan institusi, masalah kesiapan pengajar, masalah kesiapan siswa, masalah biaya investasi, masalah teknologi, masalah infrastruktur, masalah materi pembelajaran, dan belum memadainya perhatian dari berbagai pihak terhadap penerapan Open and Distance Learning (ODL) melalui internet.

Matematika adalah sebuah ilmu pasti yang mempelajari tentang perhitungan-perhitungan yang terdapat di dalam kehidupan sehari-hari [7]. Dalam dunia pendidikan, pengajaran setiap mata pelajaran, termasuk matematika, sudah dibuat dalam bentuk silabus untuk memudahkan dan menyesuaikan pengajaran pada seluruh sekolah yang menerapkan silabus tersebut. Di Indonesia, silabus mata pelajaran dibuat oleh Kementrian Pendidikan dan Kebudayaan (Kemendikbud). Pada penelitian ini, silabus yang akan dipakai adalah silabus edisi revisi 2016 kurikulum 2013 yang akan dibandingkan juga dengan kurikulum dari Khan Academy [8].

Moodle adalah sebuah program aplikasi yang digunakan untuk membantu kegiatan belajar mengajar berbasis web [9]. Moodle merupakan singkatan dari Modular Object-Oriented Dynamic Learning Environment. Konsep yang diterapkan di dalam moodle adalah konsep e-learning, sehingga kegiatan pembelajaran dapat berlangsung tanpa harus bertemu. Fitur-fitur yang tersedia pada Moodle adalah: Assignment, Chat, Forum, Lesson, Kuis, dan Survei. Alasan penggunaan Moodle adalah karena Moodle sudah digunakan dalam berbagai aplikasi pembelajaran berbasis web dan juga memiliki berbagai fitur yang dapat memenuhi kebutuhan pengembangan aplikasi pembelajaran ini. Selain itu, penelitian yang mengevaluasi platformplatform penyedia e-learning open-source menunjukkan bahwa platform Moodle mengungguli seluruh platform yang lain dan juga meraih nilai terbaik dalam kategori pemenuhan kebutuhan pengguna [10]. Hal-hal yang menjadikan Moodle sebagai platform terbaik adalah dikarenakan adanya fitur adaptif, yaitu: Lesson. Extensibility Moodle juga didukung dengan sangat baik oleh API yang didokumentasi, pedoman yang detil, dan templates untuk pemrograman.

Dengan berkembangnya teknologi informasi, banyak aplikasi maupun website yang menyediakan fasilitas untuk membantu anak-anak sekolah dalam belajar. Oleh karena adanya internet juga, aplikasi dan website tersebut dapat diakses dengan mudah dan gratis. Beberapa aplikasi ataupun website yang terkait dengan penelitian ini adalah Khan Academy [11], GeoGebra [12], dan Bebras [13] - [14].

Dalam mendukung penelitian dalam makalah ini, aplikasi akan dibuat dalam bentuk web yang menggunakan Moodle, salah satu learning management system open-source, sebagai platform. Aplikasi web ini akan diisi dengan materi mata pelajaran matematika kelas 4 SD dan akan diujikan ke salah satu sekolah di Bandung.

Berdasarkan latar belakang di atas, tujuan makalah ini adalah untuk menyediakan LMS sebagai alat pembelajaran pada anak-anak Sekolah Dasar, kemudian melakukan evaluasi pengujian penggunaan LMS tersebut bagi pembelajaran anak-anak Sekolah Dasar. Melalui penelitian ini, diharapkan aplikasi pembelajaran berbasis web dengan platform learning management system Moodle dapat memberikan pengaruh positif dalam meningkatkan minat pembelajaran serta perkembangan nilai anakanak sebelum dan sesudah menggunakan aplikasi pembelajaran ini.

\section{Metode Penelitian}

\section{A. Metodologi Penelitian}

1) Identifikasi Masalah: Matematika merupakan salah satu mata pelajaran yang wajib untuk dipelajari di sekolah. Pembelajaran matematika dinilai sulit untuk dipahami, sehingga membutuhkan waktu yang lebih lama dan penjelasan materi secara intensif. Dalam pengajaran di sekolah, pembelajaran matematika pada anak-anak dibatasi oleh waktu dan pengajar yang tidak dapat fokus hanya pada satu anak. Sehingga, anak-anak yang membutuhkan penjelasan secara intensif membutuhkan sarana lain dalam belajar. 
2) Usulan Solusi: Dari identifikasi masalah, anak-anak dinilai membutuhkan sarana atau media lain yang mendukung pembelajaran. Usulan solusi yang diberikan dalam makalah ini adalah penerapan LMS dalam pembelajaran. Pengaksesan LMS juga tidak dibatasi oleh waktu dan tempat, sehingga anak-anak dapat secara bebas menggunakan LMS tersebut. Selain itu, LMS dapat memberikan variasi cara pembelajaran bagi siswa. Tampilan yang interaktif juga dapat mendorong anak-anak untuk belajar sendiri. Dengan memanfaatkan LMS, guru dan siswa tidak perlu bertemu secara fisik untuk melakukan proses pembelajaran.

3) Perancangan dan Implementasi: LMS yang diterapkan pada penelitian ini adalah Moodle. Aplikasi LMS yang berbasis web ini memerlukan instalasi dan setting keperluan yang dibutuhkan dalam pengembangannya. Dalam aplikasi ini, materi-materi mata pelajaran matematika, yang menjadi materi pengujian dalam penelitian ini, akan dimasukkan. Sebelum dilakukan pengujian ke sekolah, aplikasi ini dijalankan oleh pengembang aplikasi terlebih dahulu untuk melihat apakah aplikasi dengan platform Moodle ini sudah berjalan sesuai kebutuhan.

4) Pengujian: Setelah aplikasi ini dinilai sudah siap untuk diujikan, maka pengujian ke sekolah dilakukan untuk mendapatkan data-data yang dibutuhkan dalam penelitian ini. Pengujian dilakukan dengan anak-anak mengakses materi pembelajaran dan mengerjakan soal latihan terlebih dahulu. Setelah itu, anak-anak mengerjakan soal kuis yang telah disiapkan dan hasil kuis yang didapatkan menjadi salah satu data yang akan dianalisis. Pengaksesan aplikasi dapat dilakukan di luar pengujian.

5) Evaluasi: Setelah melakukan pengujian aplikasi, data-data yang didapatkan akan dianalisis. Data-data yang didapatkan berupa hasil nilai kuis, lama waktu pengerjaan, frekuensi pengaksesan latihan, dan data-data yang lain. Evaluasi penerapan LMS dilakukan berdasarkan hasil analisis data yang didapatkan.

6) Studi Kasus: Penelitian ini melibatkan 15 anak-anak kelas 4 SD di salah satu sekolah. Pengujian dilakukan di laboratorium komputer sekolah tersebut. Materi mata pelajaran matematika yang dimasukkan ke dalam aplikasi ini adalah materi Pecahan.

\section{B. Rancangan Sistem}

Berikut adalah rancangan sistem yang dibangun untuk penelitian ini.

1) Gambaran Aplikasi: Fungsi utama perangkat lunak yang akan dibangun adalah aplikasi dapat menampilkan teori-teori beserta latihan soal sesuai dengan materi, memberikan fasilitas untuk kuis atau ujian, memberikan informasi hasil kuis atau ujian kepada pengguna, dan menampilkan pembahasan soal-soal pada latihan maupun kuis.

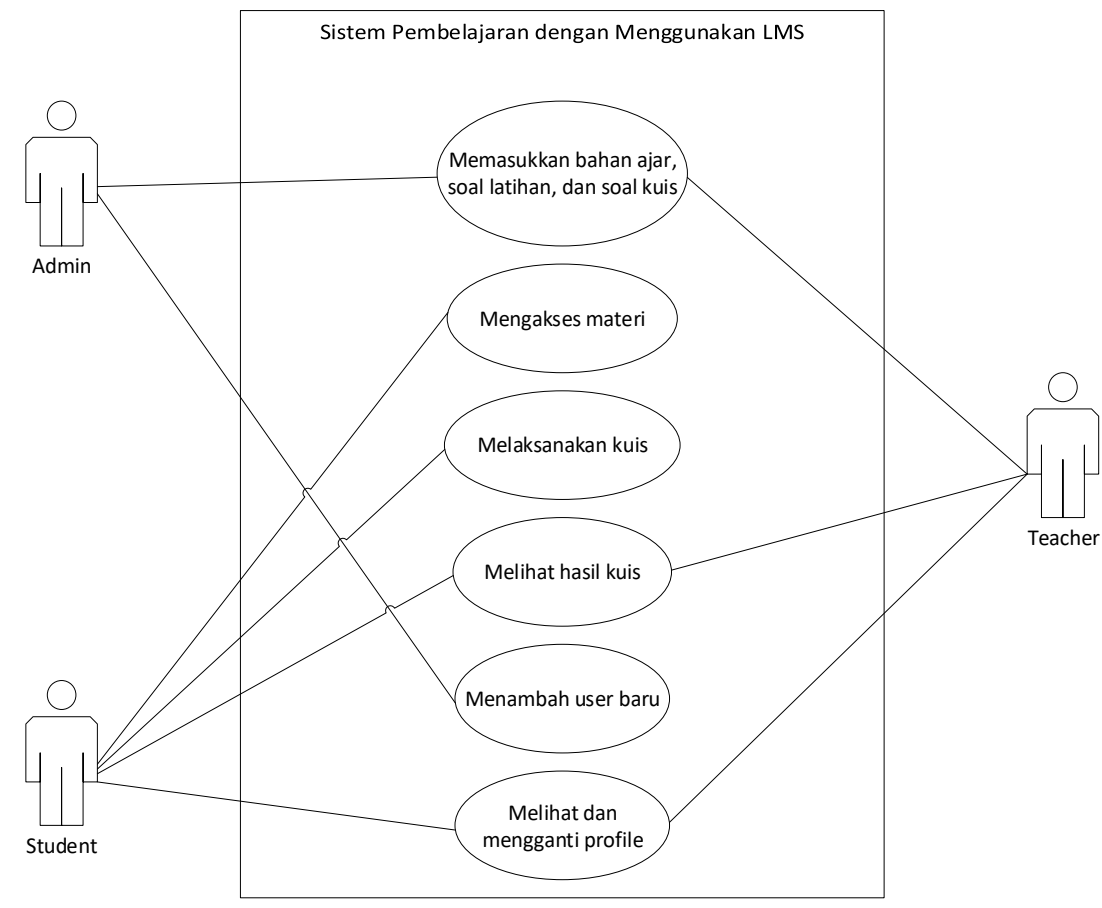

Gambar 1. Use Case Diagram Pengembangan Aplikasi 
2) Unified Modeling Language (UML) Use Case Diagram: Gambar 1 adalah use case diagram dari aplikasi pembelajaran yang akan dibuat untuk menganalisis implementasi LMS terhadap pembelajaran pada anak-anak sekolah dasar terkait mata pelajaran matematika. Pengguna aplikasi terdiri dari tiga peran, yaitu: Admin, Teacher, dan Student. Admin berperan untuk menambahkan pengguna Teacher dan pengguna Student ke dalam aplikasi. Selain itu, Admin juga berperan untuk memasukkan daftar mata pelajaran yang tersedia di dalam aplikasi. Daftar mata pelajaran tersebut dapat diakses oleh pengguna Teacher untuk diisikan materi-materi pembelajaran yang sesuai. Admin juga dapat berperan sebagai pengguna Teacher dan pengguna Student. Teacher berperan untuk memasukkan bahan-bahan materi dan melihat hasil kuis yang telah dilaksanakan untuk mengetahui kemampuan student dalam menguasai materi yang telah diberikan. Student berperan untuk mempelajari materi-materi yang telah diberikan, melakukan latihan pada soal-soal tiap materi, dan kemudian melaksanakan kuis yang tersedia di dalam materi.

\section{Alur Implementasi dan Penggunaan}

Gambar 2 merupakan gambaran langkah-langkah implementasi dan penggunaan aplikasi dalam penelitian ini.

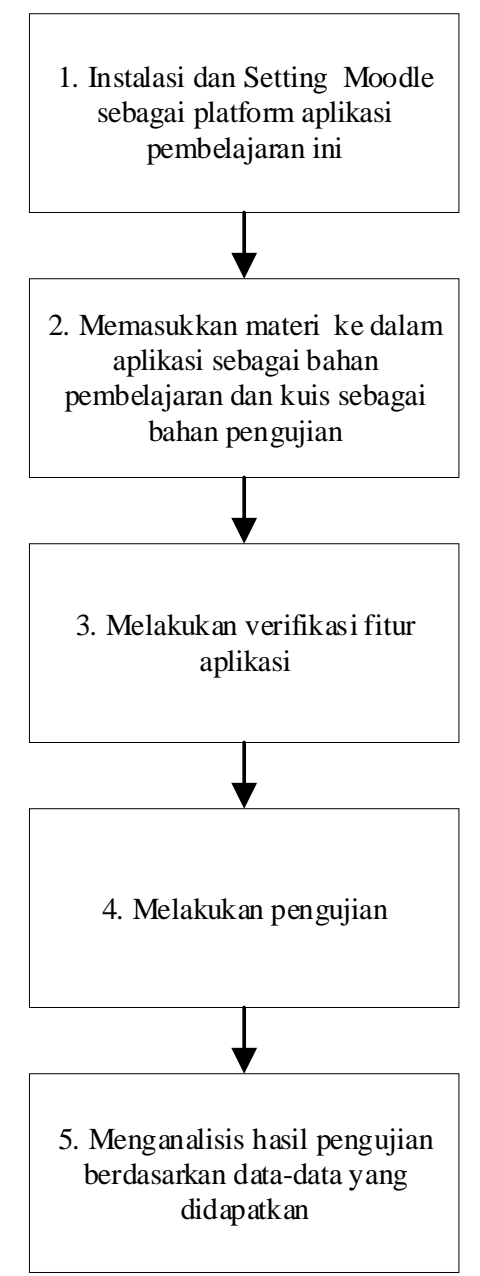

Gambar 2. Alur Implementasi dan Penggunaan

Berikut penjelasan singkat alur implementasi dan penggunaan tersebut:

1. Instalasi dan konfigurasi Moodle sebagai platform aplikasi pembelajaran ini.

Untuk memulai proses instalasi, dibutuhkan file installer Moodle yang dapat diunduh melalui website https://download.moodle.org/. Setelah pengunduhan selesai, ekstrak file tersebut menjadi bentuk folder yang bernama Moodle. Setelah itu, folder Moodle tersebut diunggah ke cpanel website yang digunakan Moodle. Proses instalasi dapat dimulai, setelah setting yang dibutuhkan Moodle dilakukan. Instalasi selesai setelah aplikasi meminta untuk memasukkan data username untuk Admin. Untuk mendukung tampilan aplikasi yang menarik, plugins tema dapat 
dimasukkan ke dalam aplikasi. Selain tampilan yang menarik dari tema, penyajian materi dalam aplikasi juga dipertimbangkan melalui karakteristik gaya belajar anak-anak, yaitu: Visual, Auditorial, dan Kinestetik [15]. Penyajian materi dibuat dalam bentuk slideshow yang berisi gambar penjelasan materi untuk mendukung gaya belajar visual dan bentuk penjelasan materi melalui suara untuk mendukung gaya belajar auditorial. Aplikasi juga dibuat interaktif dengan memasukkan suara-suara yang dapat bekerja sesuai dengan kondisi.

2. Memasukkan materi ke dalam aplikasi sebagai bahan pembelajaran dan kuis sebagai bahan pengujian.

Setelah melakukan instalasi aplikasi, materi-materi dapat dimasukkan ke dalam aplikasi. Materi yang dimasukkan dapat disesuaikan dengan pengujian yang dilakukan. Selain materi untuk bahan pembelajaran, soal-soal kuis dapat disiapkan dan dimasukkan ke dalam aplikasi untuk mengukur kemampuan anak-anak.

3. Melakukan verifikasi fitur aplikasi.

Setelah materi dan kuis selesai dimasukkan, maka akan dilakukan verifikasi terhadap fitur-fitur aplikasi. Tahap ini adalah tahap dimana pengembang memeriksa apakah fitur-fitur di dalam aplikasi sudah berjalan sesuai dengan kebutuhan. Selain fitur-fitur, isi materi juga dapat dilakukan verifikasi apakah sudah sesuai dengan kebutuhan pengujian.

4. Melakukan pengujian.

Setelah selesai melakukan verifikasi terhadap fitur-fitur aplikasi, maka pengujian dapat dilakukan. Pengujian dilakukan sesuai dengan kebutuhan data yang diperlukan.

5. Menganalisis hasil pengujian berdasarkan data-data yang didapatkan.

Setelah selesai melakukan pengujian, data-data yang didapatkan dapat berupa hasil nilai kuis, frekuensi pengaksesan latihan, rata-rata waktu penyelesaian kuis, dan lain-lain. Data-data yang didapatkan kemudian dianalisis untuk mendapatkan suatu kesimpulan.

\section{HASIL DAN PEMBAHASAN}

\section{A. Implementasi Sistem}

Dari alur implementasi dan penggunaan, implementasi sistem yang telah dilakukan adalah Moodle yang sudah diinstal dan di-hosting ke website smartlearning.itmaranatha.org. Aplikasi ini dinamakan Smart Learning with Moodle. Pengguna dalam aplikasi ini dibagi menjadi tiga, yaitu: Admin, Teacher, dan Student.

Gambar 3 adalah tampilan yang muncul pertama kali saat aplikasi diakses. Pengguna akan diminta untuk melakukan login dan kemudian diberikan tampilan sesuai dengan role.

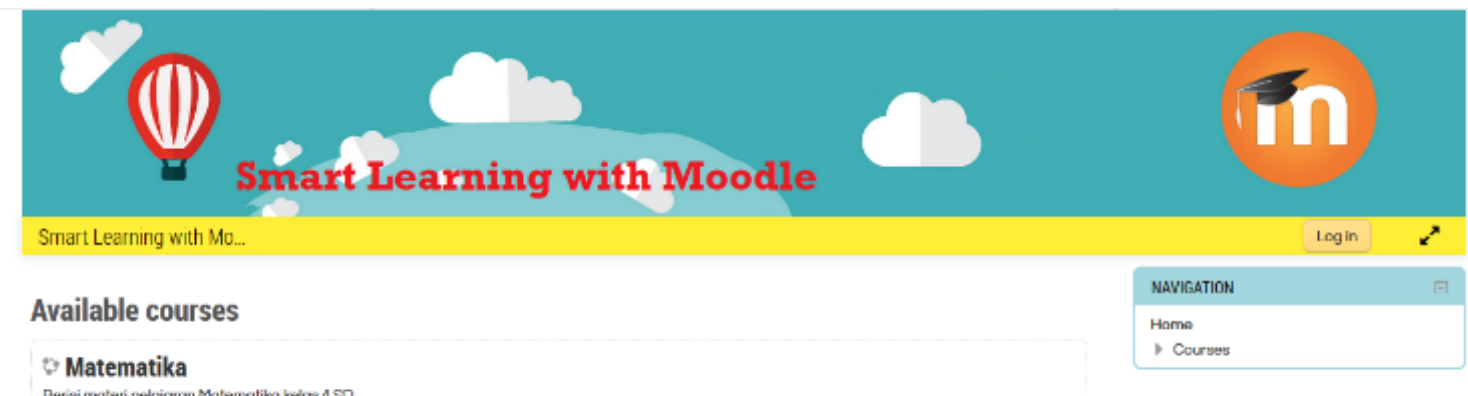

1) Implementasi Sistem Pengguna Admin: Admin dapat menambahkan pengguna yang dapat mengakses aplikasi pembelajaran ini. Untuk menambahkan pengguna, Admin mengakses site administration $>$ users $>$ accounts $>$ add a new user. Admin kemudian mengisikan data informasi pengguna, berupa username, password, first name, surname, dan email address. Setelah itu, aplikasi akan mencatat pengguna tambahan sesuai dengan data informasi yang telah dimasukkan. Selain itu, Admin juga dapat berperan menjadi student dan teacher.

2) Implementasi Sistem Pengguna Teacher: Teacher dalam aplikasi ini dapat memasukkan bahan materi ke dalam aplikasi melalui Add an activity or resource dan memilih radio button Lesson, kemudian pilih Add. Setelah itu, teacher mengisikan informasi materi dan melakukan pengaturan terlebih dahulu. Setelah membuat activity lesson, teacher 
memasukkan isi bahan materi dan soal-soal latihan untuk bahan materi tersebut. Untuk memasukkan isi bahan materi, teacher dapat memilih menu Add a content page. Untuk memasukkan soal-soal latihan, teacher dapat memilih menu Add a question page. Selain memasukkan materi pembelajaran, teacher dapat menyiapkan soal-soal kuis untuk dimasukkan ke dalam aplikasi melalui Add an activity or resource dan memilih radio button Quiz. Kuis dibuat untuk menguji penguasaan materi oleh student dan data hasil kuis dapat diakses oleh teacher. Selain data hasil kuis, teacher juga dapat mengakses data-data yang tersimpan di dalam log Moodle sebagai bahan analisis perkembangan student.

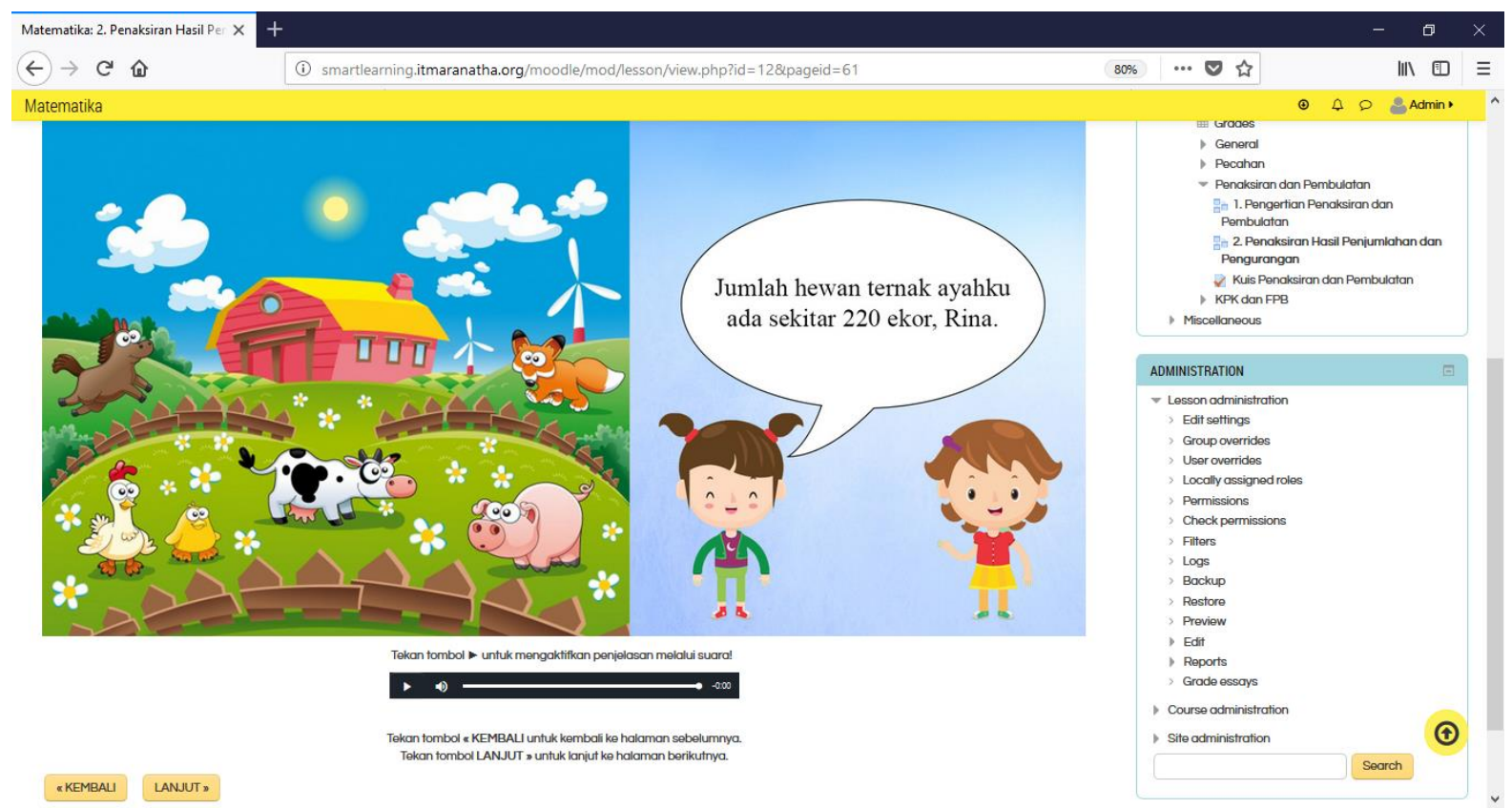

Gambar 4. Tampilan Penyajian Isi Materi

3) Implementasi Sistem Pengguna Student: Pengguna Student dapat mengakses materi-materi yang telah tersedia dengan memilih judul materi yang ingin diakses. Setelah itu, aplikasi akan menampilkan isi materi yang telah diisi. Student dapat mempelajari

isi

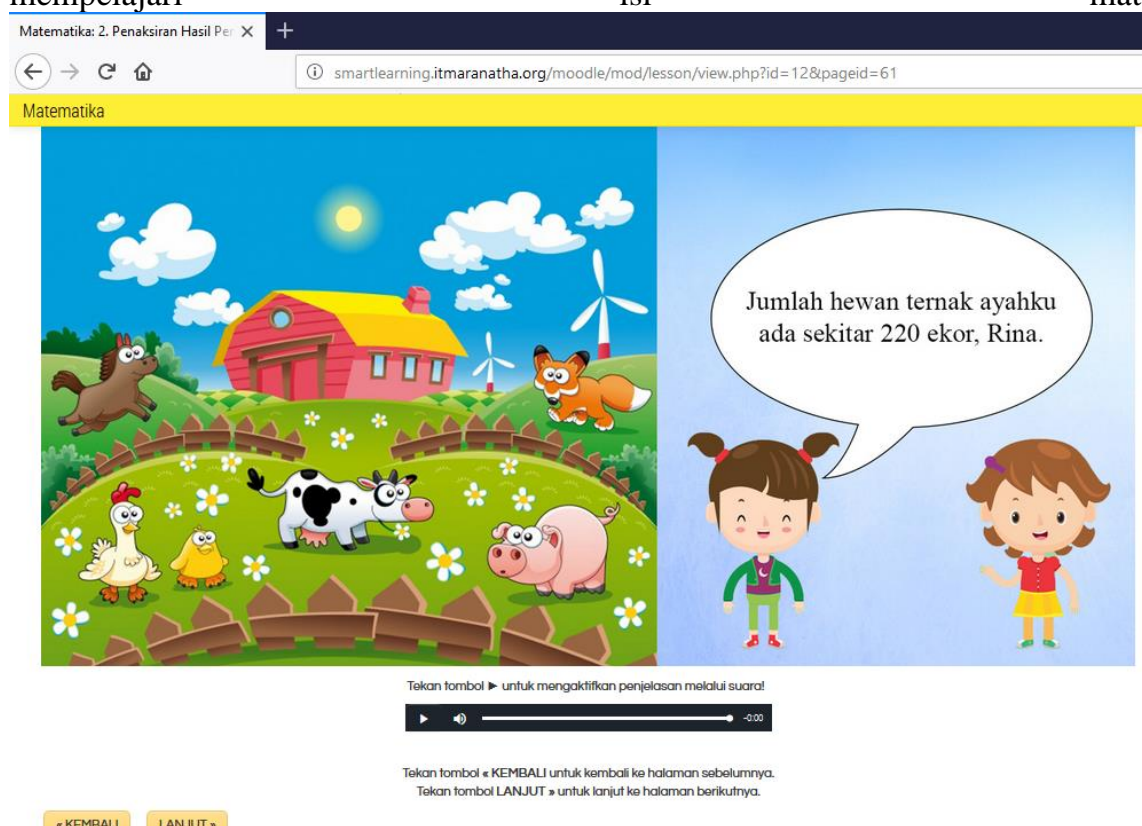

tersebut.

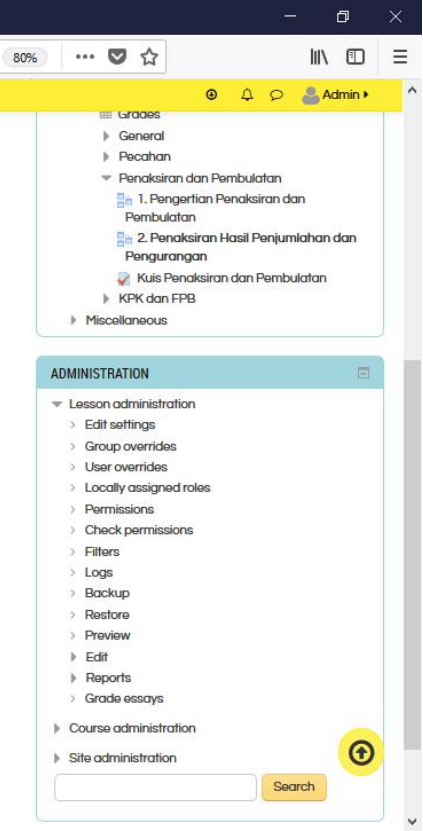


4) Gambar 4 adalah tampilan penyajian isi materi. Materi di dalam aplikasi pembelajaran ini disajikan dengan bentuk gambar ilustrasi dan penjelasan suara yang aktif ketika pengguna student mengakses isi materi. Setelah mengakses isi materi, pengguna student dapat mengerjakan soal latihan yang tersedia di dalam materi.

Gambar 5 adalah tampilan contoh soal latihan yang tersedia di dalam materi. Apabila student menjawab soal latihan dengan benar, aplikasi akan mengeluarkan suara yang menandakan jawaban benar. Sedangkan, apabila student menjawab soal latihan dengan salah, aplikasi akan mengeluarkan suara yang menandakan jawaban yang salah. Selain mengeluarkan suara penanda jawaban benar dan salah ketika pengguna student menjawab soal latihan, aplikasi juga akan menampilkan pembahasan soal latihan tersebut. Ketika pengguna student menjawab soal dengan benar, aplikasi akan menampilkan pembahasan soal latihan tersebut dan aplikasi akan mengarahkan pengguna student ke soal selanjutnya.

Gambar 6 adalah tampilan ketika pengguna student menjawab soal latihan dengan benar.

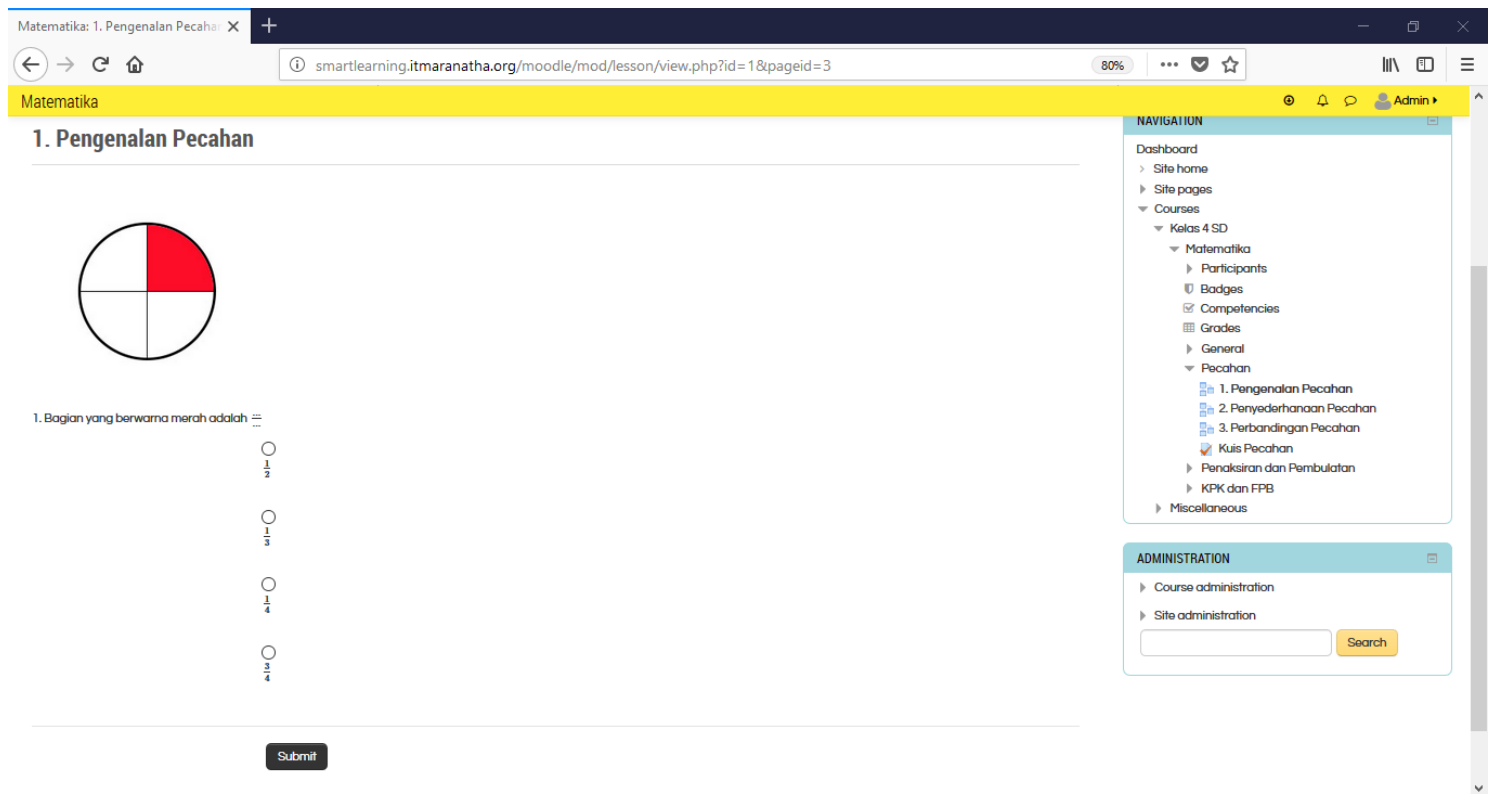

Gambar 5. Tampilan Soal Latihan Materi

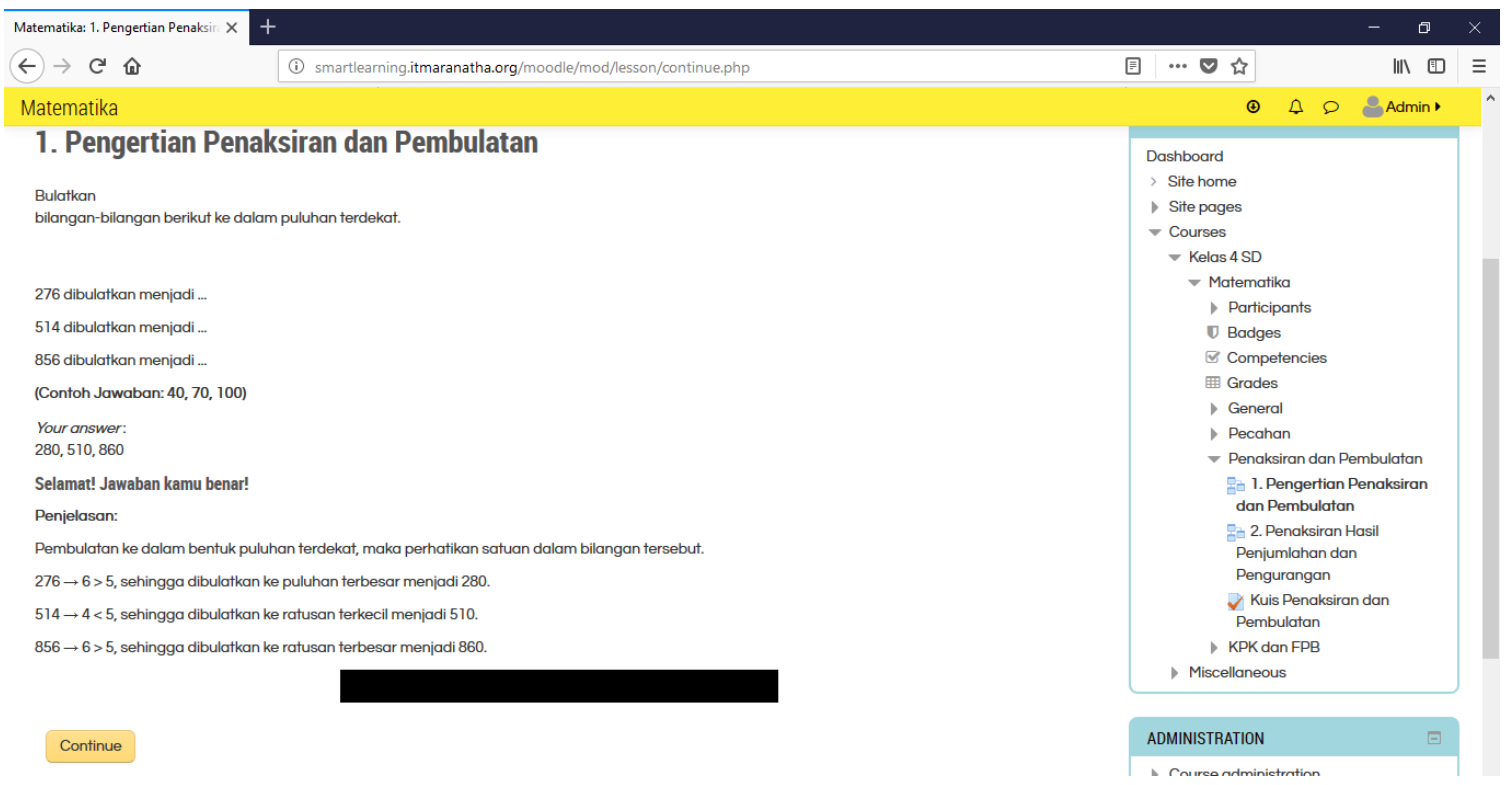

Gambar 6. Tampilan Jawab Latihan dengan Benar 
Sedangkan, ketika pengguna student menjawab soal dengan salah, aplikasi akan menampilkan pembahasan soal latihan tersebut dan akan mengarahkan pengguna student untuk menjawab kembali soal tersebut. Aplikasi akan memberikan tiga kali kesempatan bagi pengguna student. Apabila pengguna student tetap menjawab soal dengan salah, aplikasi akan langsung mengarahkan pengguna student ke soal berikutnya. Gambar 7 adalah tampilan ketika pengguna student menjawab soal latihan dengan salah.

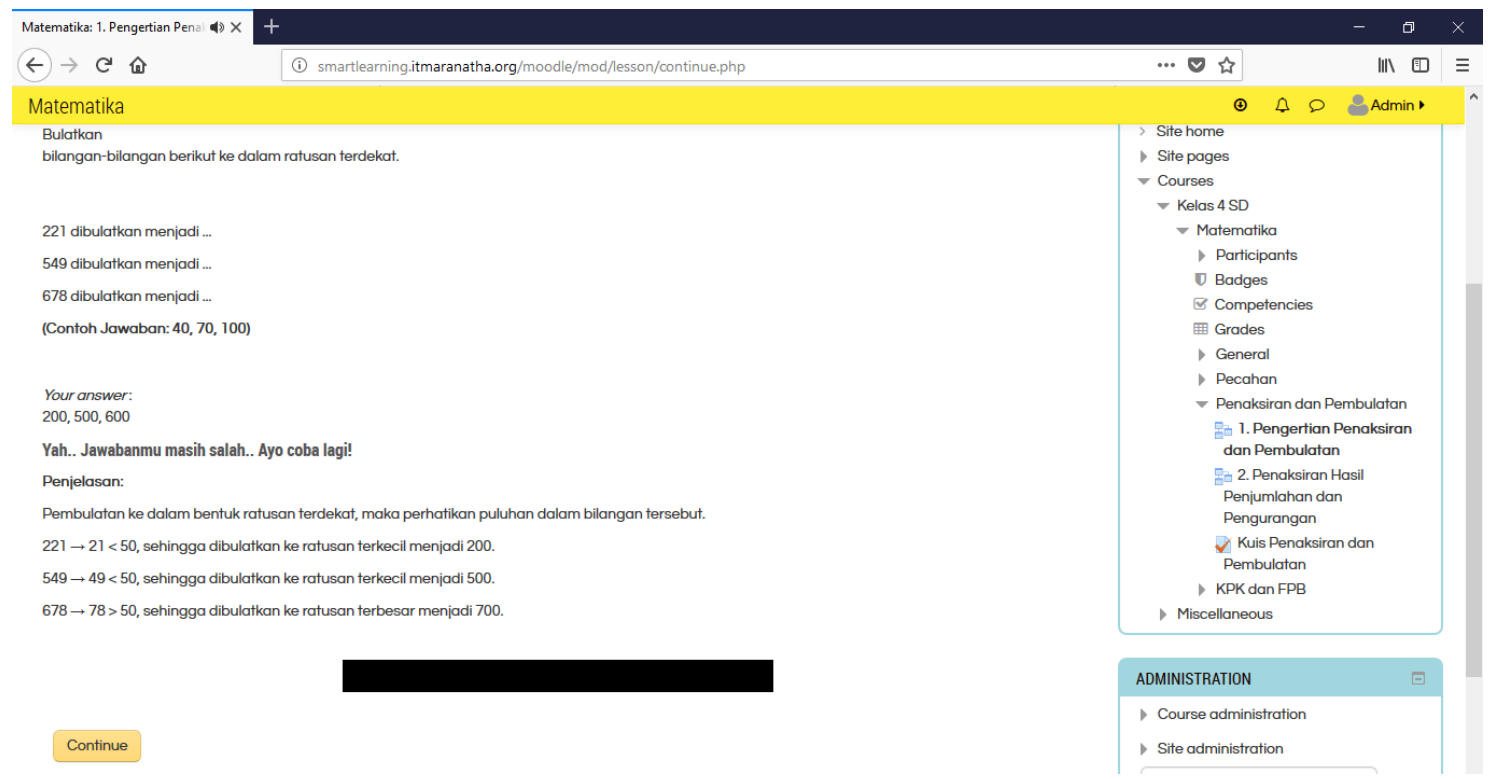

Gambar 7. Tampilan Jawab Latihan dengan Salah

Setelah mengakses materi dan mengerjakan soal latihan, pengguna student dapat mengakses kuis dan mengerjakan soalsoal yang terdapat di dalamnya. Kuis hanya dapat diakses ketika bagian-bagian materi sudah terdapat tanda centang. Gambar 8 adalah tampilan aplikasi ketika kuis sudah dapat diakses.

Ketika pengguna student mengakses soal kuis, aplikasi akan menampilkan soal-soal kuis yang tersedia. Gambar 9 adalah tampilan contoh soal kuis materi yang tersedia. Setelah pengguna student menyelesaikan kuis dan melakukan submit jawaban. Aplikasi akan menampilkan nilai kuis yang diperoleh pengguna student. Gambar 10 adalah tampilan ketika kuis sudah selesai dikerjakan. Selain menampilkan nilai kuis, aplikasi juga dapat menampilkan jawaban dan pembahasan tiap-tiap soal kuis. Gambar 11 adalah tampilan jawaban dan pembahasan salah satu soal kuis.

Penaksiran dan Pembulatan
Kuis Penaksiran dan Pembulatan

Gambar 8. Tampilan Kuis Dapat Diakses 


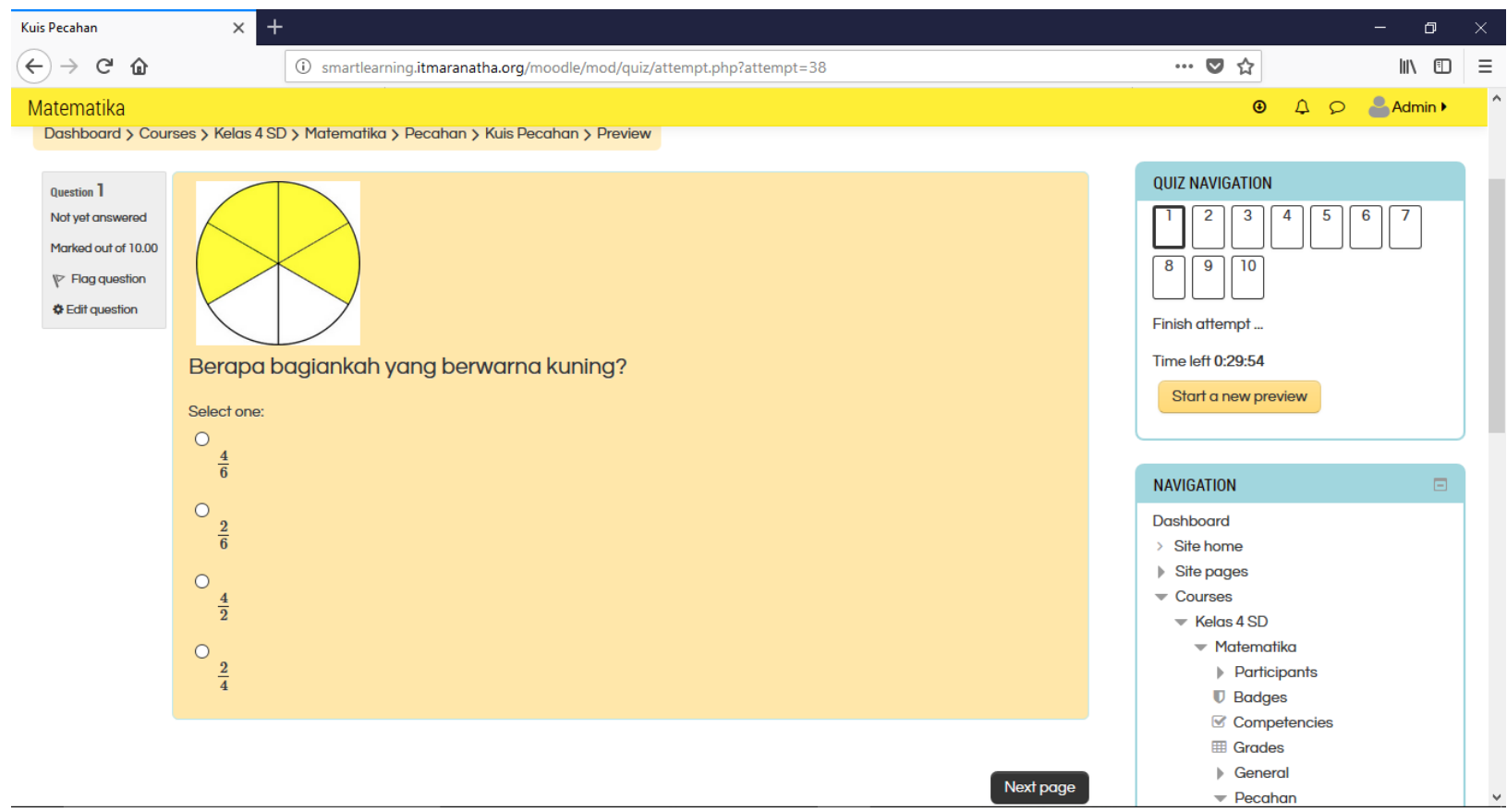

Gambar 9. Tampilan Soal Kuis

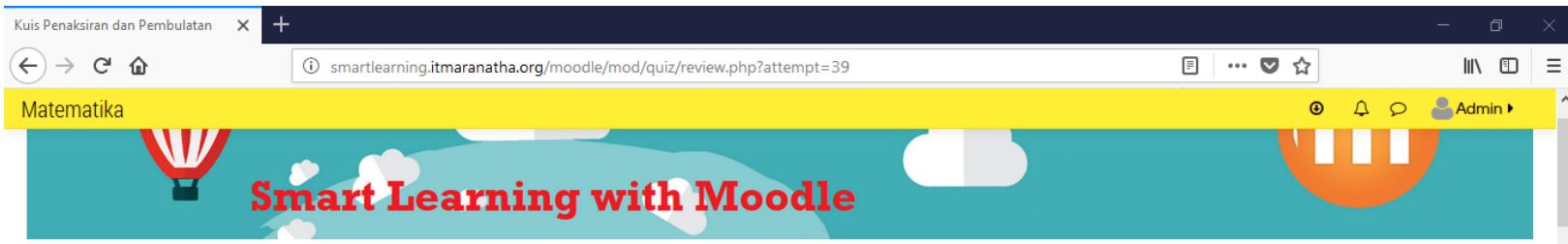

Dashboard > Courses > Kelas 4 SD > Matematika > Penaksiran dan Pembulatan > Kuis Penaksiran dan Pembulatan > Preview

Started on Tuesday, 12 December 2017, 8:22 PM

State Finished

Completed on Tuesday, 12December 2017, 8.23 PM

Time taken $1 \mathrm{~min} 35 \mathrm{secs}$

Grade 100.00 out of 100.00

Feedback Selamat!! Kamu telah menyelesaikan kuis "Penaksiran dan Pembulatan"!

\begin{tabular}{|c|c|}
\hline \multirow{2}{*}{$\begin{array}{l}\text { Question } 1 \\
\text { Correct }\end{array}$} & Bulatkanlah bilangan berikut ke dalam bentuk puluhan terdekat, ratusan terdekat, dan ribuan terdeka \\
\hline & $4365 \%$... (puluhan terdekat) \\
\hline Mark 15.00 out of & $4365 \approx$... (ratusan terdekat) \\
\hline & $4365 \%$...(ribuan terdekat) \\
\hline P Flag question & (Contoh jawaban: $6750,6800,7000$ ) \\
\hline Edit question & Ancwer $4370-4400-4000$ \\
\hline
\end{tabular}

Gambar 10. Tampilan Kuis Selesai
QUIZ NAVIGATION

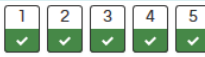

Show one page at a time

Finish review

Start a new preview

NAVIGATION

Dashboard

Site home

Site pages

Courses

$\checkmark$ Kelas 4SD

Matematikn 

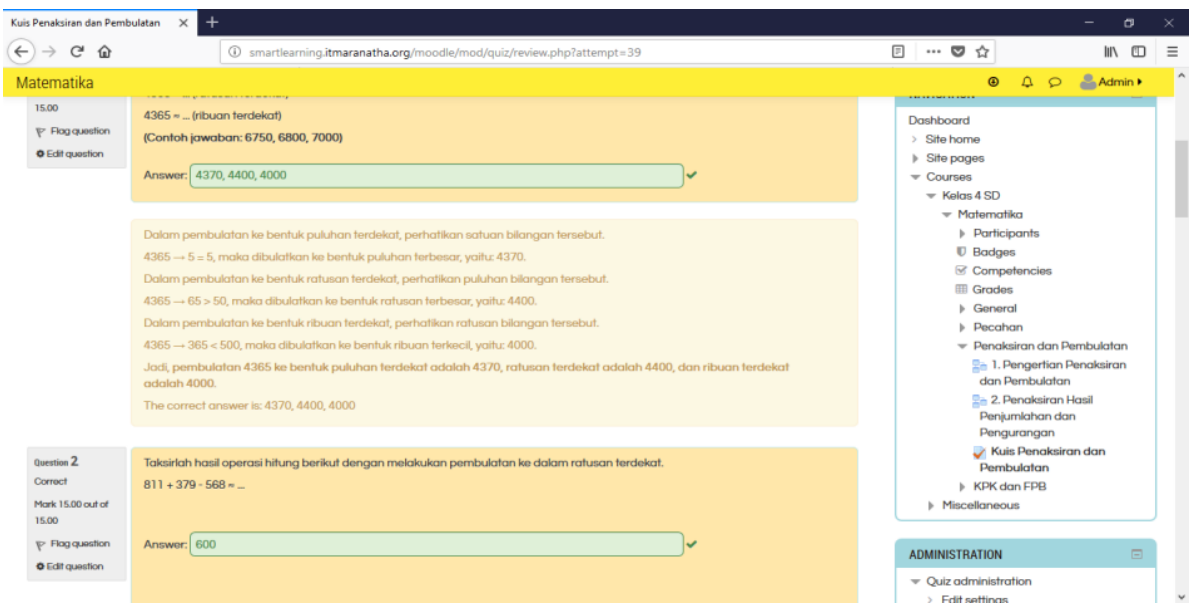

Gambar 11. Tampilan Pembahasan Soal Kuis

\section{B. Hasil Penelitian}

Untuk melakukan evaluasi penerapan LMS Moodle pada pembelajaran matematika sekolah dasar, maka dilakukan pengujian aplikasi ini terhadap anak-anak sekolah dasar. Pengujian pada penelitian ini melibatkan 15 anak-anak SD kelas 4 . Pengujian aplikasi tersebut dilakukan sebanyak dua kali dengan pengujian pertama berupa pengaksesan materi dan pengerjaan latihan soal dan pengujian kedua berupa pengerjaan kuis. Pengujian pertama dilakukan pada hari Selasa tanggal 3 Oktober 2017 di laboratorium komputer sekolah pukul 12.10-13.15. Pengujian kedua dilakukan pada hari Selasa tanggal 10 Oktober 2017 di laboratorium komputer sekolah pukul 11.30-12.30. Materi yang diujikan adalah materi Pecahan dengan rincian materi yang dimasukkan ke dalam aplikasi terdapat pada Tabel 1.

TABEL 1

MATERI PECAHAN

\begin{tabular}{cll}
\hline Materi & \multicolumn{1}{c}{ Pecahan } \\
\hline Bagian & \multicolumn{2}{c}{ Topik Materi } \\
\hline \multirow{2}{*}{$\mathbf{2}$} & \multicolumn{2}{l}{ Pengenalan Pecahan } \\
\cline { 2 - 3 } & $1.1 \quad$ Apa itu Pecahan? \\
\cline { 2 - 3 } & $1.2 \quad$ Letak Pecahan dalam Garis Bilangan \\
\hline & Penyederhanaan Pecahan \\
\cline { 2 - 3 } & $2.1 \quad$ Pecahan Senilai \\
\hline \multirow{3}{*}{$2.2 \quad$ Menyederhanakan Pecahan } \\
\hline
\end{tabular}

Selain memasukkan materi pembelajaran dan soal-soal latihan per materi, soal-soal kuis juga disiapkan dan dimasukkan ke dalam aplikasi untuk mendapatkan data nilai tes anak-anak setelah menggunakan aplikasi. Gambar 12 adalah contoh soal kuis yang digunakan untuk melakukan pengujian.

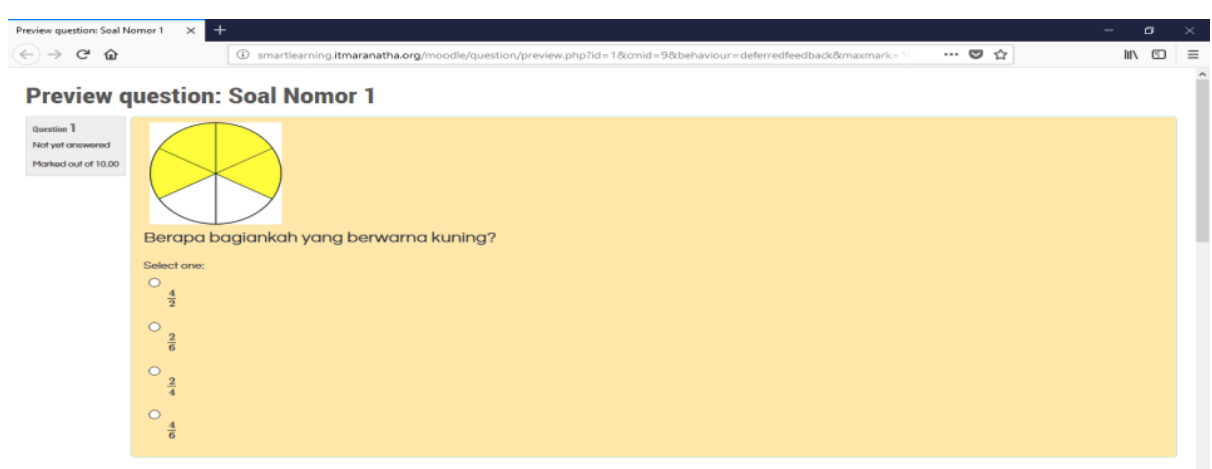

Gambar 12. Contoh Soal Kuis Pengujian 
1) Hasil Analisis Perbandingan Nilai Tes Tertulis Dengan Nilai Kuis Aplikasi: Tabel 2 merupakan perbandingan nilai tes tertulis dan nilai kuis aplikasi anak-anak.

TABEL 2

Perbandingan Nilai Tes Tertulis Dengan Nilai Kuis APliKas

\begin{tabular}{|c|c|c|c|}
\hline No. & Username & Hasil Tes Tertulis & Hasil Kuis (Alat Bantu) \\
\hline 1 & Student 15 & 76 & 93.33 \\
\hline 2 & Student 16 & 76 & 85 \\
\hline 3 & Student 11 & 80 & 83.33 \\
\hline 4 & Student 07 & 84 & 83.33 \\
\hline 5 & Student 14 & 80 & 83.33 \\
\hline 6 & Student 09 & 70 & 83.33 \\
\hline 7 & Student 01 & 56 & 80 \\
\hline 8 & Student 10 & 74 & 78.33 \\
\hline 9 & Student 13 & 80 & 73.33 \\
\hline 10 & Student 12 & 60 & 73.33 \\
\hline 11 & Student 06 & 80 & 73.33 \\
\hline 12 & Student 05 & 80 & 70 \\
\hline 13 & Student 03 & 36 & 70 \\
\hline 14 & Student 08 & 80 & 70 \\
\hline 15 & Student 02 & 64 & 43.33 \\
\hline & Rata-Rata Nilai & 71.73 & 76.22 \\
\hline & Nilai Tertinggi & 84 & 93.33 \\
\hline & Nilai Terendah & 36 & 43.33 \\
\hline & Standar Deviasi & 12.89 & 11.38 \\
\hline
\end{tabular}

Analisis T-Test dilakukan terhadap data pada Tabel 2. T-Test yang digunakan adalah paired T-Test dimana analisis data dilakukan dengan membandingkan hasil uji dua sampel berpasangan dengan kelompok anak-anak yang sama namun mendapatkan perlakuan yang berbeda, yaitu: nilai tes tertulis sebelum menggunakan aplikasi dengan nilai kuis sesudah menggunakan aplikasi. Hipotesis yang diharapkan adalah adanya perbedaan signifikan. Namun, dari hasil p-value yang bernilai 0.2492 adalah lebih besar dari 0.05 . Hal itu menunjukkan tidak ada perbedaan yang signifikan antara sebelum menggunakan aplikasi dan sesudah menggunakan aplikasi.

Rata-rata nilai pada tes tertulis adalah 71.73 dan setelah diadakan kuis aplikasi dengan mencoba aplikasi pembelajaran tersebut adalah 76.22 yang berarti mengalami kenaikan sebesar $6.26 \%$ atau 4.49 lebih tinggi dari rata-rata nilai tes tertulis. Selain itu, nilai tertinggi setelah menggunakan aplikasi juga mengalami kenaikan dari 84 pada tes tertulis menjadi 93.33 pada kuis aplikasi. Nilai terendah juga mengalami kenaikan dari 36 pada tes tertulis menjadi 43.33 pada kuis aplikasi. Selain itu, standar deviasi juga mengalami penurunan dari 12.89 pada tes tertulis menjadi 11.38 pada kuis aplikasi. Untuk perbandingan nilai tes antara hasil tes tertulis sebelum menggunakan aplikasi dan hasil kuis setelah menggunakan aplikasi, sebanyak $60 \%$ anak mengalami peningkatan nilai tes. Peningkatan paling signifikan dialami oleh Student 03 dengan peningkatan nilai sebesar 34 poin, sedangkan penurunan paling signifikan dialami oleh Student 02 dengan penurunan nilai sebesar 20.67 poin. Dikarenakan waktu pengujian dan lingkup pengujian yang terbatas, hipotesis yang diharapkan tidak dapat tercapai.

2) Hasil Analisis Hubungan Lama Penyelesaian Dengan Jawaban Kuis: Tabel 3 merupakan tabel waktu penyelesaian dengan jawaban kuis.

TABEL 3

DATA LAMA PENYELESAIAN DAN JAWABAN KUIS

\begin{tabular}{|c|c|c|c|c|c|c|}
\hline No. & Username & Waktu & Nilai & Benar Semua & Benar Sebagian & Salah \\
\hline 1 & Student 15 & 5 menit 25 detik & 93.33 & $90 \%$ & $10 \%$ & $0 \%$ \\
\hline 2 & Student 16 & 13 menit 30 detik & 85 & $80 \%$ & $10 \%$ & $10 \%$ \\
\hline 3 & Student 11 & 11 menit 11 detik & 83.33 & $80 \%$ & $10 \%$ & $10 \%$ \\
\hline 4 & Student 07 & 11 menit 33 detik & 83.33 & $80 \%$ & $10 \%$ & $10 \%$ \\
\hline 5 & Student 14 & 12 menit 22 detik & 83.33 & $80 \%$ & $10 \%$ & $10 \%$ \\
\hline 6 & Student 09 & 13 menit 12 detik & 83.33 & $80 \%$ & $10 \%$ & $10 \%$ \\
\hline 7 & Student 01 & 12 menit 17 detik & 80 & $80 \%$ & $0 \%$ & $20 \%$ \\
\hline 8 & Student 10 & 11 menit 25 detik & 78.33 & $70 \%$ & $20 \%$ & $10 \%$ \\
\hline 9 & Student 13 & 9 menit 15 detik & 73.33 & $70 \%$ & $10 \%$ & $20 \%$ \\
\hline
\end{tabular}




\begin{tabular}{lllllll}
\hline No. & Username & Waktu & Nilai & Benar Semua & Benar Sebagian & Salah \\
\hline $\mathbf{1 0}$ & Student 12 & 10 menit 52 detik & 73.33 & $70 \%$ & $10 \%$ & $20 \%$ \\
\hline $\mathbf{1 1}$ & Student 06 & 12 menit 58 detik & 73.33 & $70 \%$ & $10 \%$ & $20 \%$ \\
\hline $\mathbf{1 2}$ & Student 05 & 12 menit 5 detik & 70 & $70 \%$ & $0 \%$ & $30 \%$ \\
\hline $\mathbf{1 3}$ & Student 03 & 13 menit 40 detik & 70 & $70 \%$ & $0 \%$ & $30 \%$ \\
\hline $\mathbf{1 4}$ & Student 08 & 26 menit 52 detik & 70 & $70 \%$ & $0 \%$ & $30 \%$ \\
\hline $\mathbf{1 5}$ & Student 02 & 12 menit 41 detik & 43.33 & $40 \%$ & $10 \%$ & $50 \%$ \\
\hline Rata-Rata & $\mathbf{1 2}$ menit 37.2 detik & $\mathbf{7 6 . 2 2}$ & & & \\
\hline
\end{tabular}

Dari hasil kuis pada Tabel 3, Student 15 yang mendapatkan nilai tertinggi, yaitu: 93.33 memiliki waktu pengerjaan kuis yang paling cepat, yaitu: 5 menit 25 detik dengan berhasil menjawab soal kuis dengan rincian 9 soal benar dan 1 soal benar sebagian. Sementara, Student 02 yang mendapatkan nilai terendah, yaitu: 43.33 memiliki waktu pengerjaan yang lebih lambat 3.8 detik dari waktu rata-rata yang dibutuhkan untuk mengerjakan kuis, yaitu: 12 menit 41 detik dengan berhasil menjawab soal kuis dengan rincian 4 soal benar, 1 soal benar sebagian, dan 5 soal salah. Sementara Student 08 yang mengerjakan kuis paling lambat, yaitu: 26 menit 52 detik mendapatkan nilai di bawah rata-rata, yaitu: 70 dengan berhasil menjawab 7 soal benar dan 3 soal salah. Dari hasil di atas, kecepatan dalam menjawab soal-soal kuis dinilai dapat mempengaruhi nilai yang diperoleh. Student yang sudah menguasai materi cenderung akan menjawab soal dengan cepat.

3) Hasil Analisis Jawaban Student Per Materi: Tabel 4 merupakan tabel jawaban student per materi.

TABEL 4

Data Jawaban Kuis ANAK-ANAK PER Materi

\begin{tabular}{lllllllllll}
\hline \multirow{2}{*}{ No. } & Username & \multicolumn{3}{c}{ Materi Bab 1 } & \multicolumn{3}{c}{ Materi Bab 2 } & \multicolumn{3}{c}{ Materi Bab 3 } \\
\cline { 3 - 10 } & & BS & BP & S & BS & BP & S & BS & BP & S \\
\hline $\mathbf{1}$ & Student 15 & $100 \%$ & $0 \%$ & $0 \%$ & $100 \%$ & $0 \%$ & $0 \%$ & $75 \%$ & $25 \%$ & $0 \%$ \\
\hline $\mathbf{2}$ & Student 16 & $66.67 \%$ & $33.33 \%$ & $0 \%$ & $66.67 \%$ & $0 \%$ & $33.33 \%$ & $100 \%$ & $0 \%$ & $0 \%$ \\
\hline $\mathbf{3}$ & Student 07 & $100 \%$ & $0 \%$ & $0 \%$ & $66.67 \%$ & $0 \%$ & $33.33 \%$ & $75 \%$ & $25 \%$ & $0 \%$ \\
\hline $\mathbf{4}$ & Student 09 & $100 \%$ & $0 \%$ & $0 \%$ & $66.67 \%$ & $0 \%$ & $33.33 \%$ & $75 \%$ & $25 \%$ & $0 \%$ \\
\hline $\mathbf{5}$ & Student 11 & $100 \%$ & $0 \%$ & $0 \%$ & $66.67 \%$ & $0 \%$ & $33.33 \%$ & $75 \%$ & $25 \%$ & $0 \%$ \\
\hline $\mathbf{6}$ & Student 14 & $100 \%$ & $0 \%$ & $0 \%$ & $66.67 \%$ & $0 \%$ & $33.33 \%$ & $75 \%$ & $25 \%$ & $0 \%$ \\
\hline $\mathbf{7}$ & Student 01 & $100 \%$ & $0 \%$ & $0 \%$ & $66.67 \%$ & $0 \%$ & $33.33 \%$ & $75 \%$ & $0 \%$ & $25 \%$ \\
\hline $\mathbf{8}$ & Student 10 & $100 \%$ & $0 \%$ & $0 \%$ & $33.33 \%$ & $33.33 \%$ & $33.33 \%$ & $75 \%$ & $25 \%$ & $0 \%$ \\
\hline $\mathbf{9}$ & Student 06 & $100 \%$ & $0 \%$ & $0 \%$ & $66.67 \%$ & $0 \%$ & $33.33 \%$ & $50 \%$ & $25 \%$ & $25 \%$ \\
\hline $\mathbf{1 0}$ & Student 12 & $100 \%$ & $0 \%$ & $0 \%$ & $100 \%$ & $0 \%$ & $0 \%$ & $25 \%$ & $25 \%$ & $50 \%$ \\
\hline $\mathbf{1 1}$ & Student 13 & $100 \%$ & $0 \%$ & $0 \%$ & $66.67 \%$ & $0 \%$ & $33.33 \%$ & $50 \%$ & $25 \%$ & $25 \%$ \\
\hline $\mathbf{1 2}$ & Student 03 & $100 \%$ & $0 \%$ & $0 \%$ & $33.33 \%$ & $0 \%$ & $66.67 \%$ & $75 \%$ & $0 \%$ & $25 \%$ \\
\hline $\mathbf{1 3}$ & Student 05 & $100 \%$ & $0 \%$ & $0 \%$ & $33.33 \%$ & $0 \%$ & $66.67 \%$ & $75 \%$ & $0 \%$ & $25 \%$ \\
\hline $\mathbf{1 4}$ & Student 08 & $100 \%$ & $0 \%$ & $0 \%$ & $33.33 \%$ & $0 \%$ & $66.67 \%$ & $75 \%$ & $0 \%$ & $25 \%$ \\
\hline $\mathbf{1 5}$ & Student 02 & $100 \%$ & $0 \%$ & $0 \%$ & $0 \%$ & $0 \%$ & $100 \%$ & $25 \%$ & $25 \%$ & $50 \%$ \\
\hline
\end{tabular}

Dari data yang didapatkan pada Tabel 4, soal-soal kuis yang merupakan materi bab 1 adalah soal yang sangat mudah karena persentase anak-anak menjawab tanpa kesalahan adalah 100\%. Soal-soal kuis yang merupakan materi bab 2 adalah soal yang paling sulit karena persentase anak-anak menjawab tanpa kesalahan hanya $13.33 \%$. Soal-soal kuis yang merupakan materi bab 3 adalah soal yang memiliki tingkat kesulitan menengah karena persentase anak-anak yang menjawab tanpa kesalahan adalah $46.67 \%$.

4) Hasil Analisis Statistik Soal Kuis: Tabel 5 merupakan tabel data statistik soal kuis.

TABEL 5

DATA STATISTIK SOAL KUIS

\begin{tabular}{lllrrr}
\hline Q\# & Bab Materi & Tipe Pertanyaan & Facility Index & Standard Deviation & Discrimination Index \\
\hline $\mathbf{1}$ & Bab 1 & Multiple choice & $100.00 \%$ & $0.00 \%$ & \\
\hline $\mathbf{2}$ & Bab 1 & Multiple choice & $100.00 \%$ & $0.00 \%$ & \\
\hline $\mathbf{3}$ & Bab 2 & Multiple choice & $93.33 \%$ & $25.82 \%$ & $68.98 \%$ \\
\hline $\mathbf{4}$ & Bab 2 & Multiple choice & $40.00 \%$ & $50.71 \%$ & $-8.82 \%$ \\
\hline $\mathbf{5}$ & Bab 2 & Short answer & $43.33 \%$ & $49.52 \%$ & $1.50 \%$ \\
\hline
\end{tabular}




\begin{tabular}{lllrrr}
\hline Q\# & Bab Materi & Tipe Pertanyaan & Facility Index & Standard Deviation & Discrimination Index \\
\hline $\mathbf{6}$ & Bab 3 & Short answer & $80.00 \%$ & $41.40 \%$ & $33.35 \%$ \\
\hline $\mathbf{7}$ & Bab 3 & Short answer & $86.67 \%$ & $35.19 \%$ & $-20.29 \%$ \\
\hline $\mathbf{8}$ & Bab 3 & Multiple choice & $80.00 \%$ & $41.40 \%$ & $33.35 \%$ \\
\hline $\mathbf{9}$ & Bab 3 & Matching & $42.22 \%$ & $32.04 \%$ & $-29.92 \%$ \\
\hline $\mathbf{1 0}$ & Bab 1 & Matching & $96.67 \%$ & $12.91 \%$ & $-31.72 \%$ \\
\hline
\end{tabular}

Soal nomor 1 dan nomor 2 adalah soal yang paling mudah dikerjakan karena memiliki facility index tertinggi, yaitu: 100\% dan standard deviation terendah, yaitu: $0 \%$. Untuk soal yang paling bagus, dapat diketahui melalui nilai discrimination index. Semakin tinggi nilai discrimination index, maka semakin bagus soal tersebut. Soal nomor 3 memiliki discrimination index tertinggi, sehingga soal tersebut dinilai merupakan soal yang paling bagus karena efektif dalam memilah student yang mampu dan yang kurang mampu.

5) Hasil Analisis Pengaruh Frekuensi Latihan Terhadap Nilai Kuis: Gambar 13 merupakan diagram scatter plot antara frekuensi latihan dan nilai kuis.

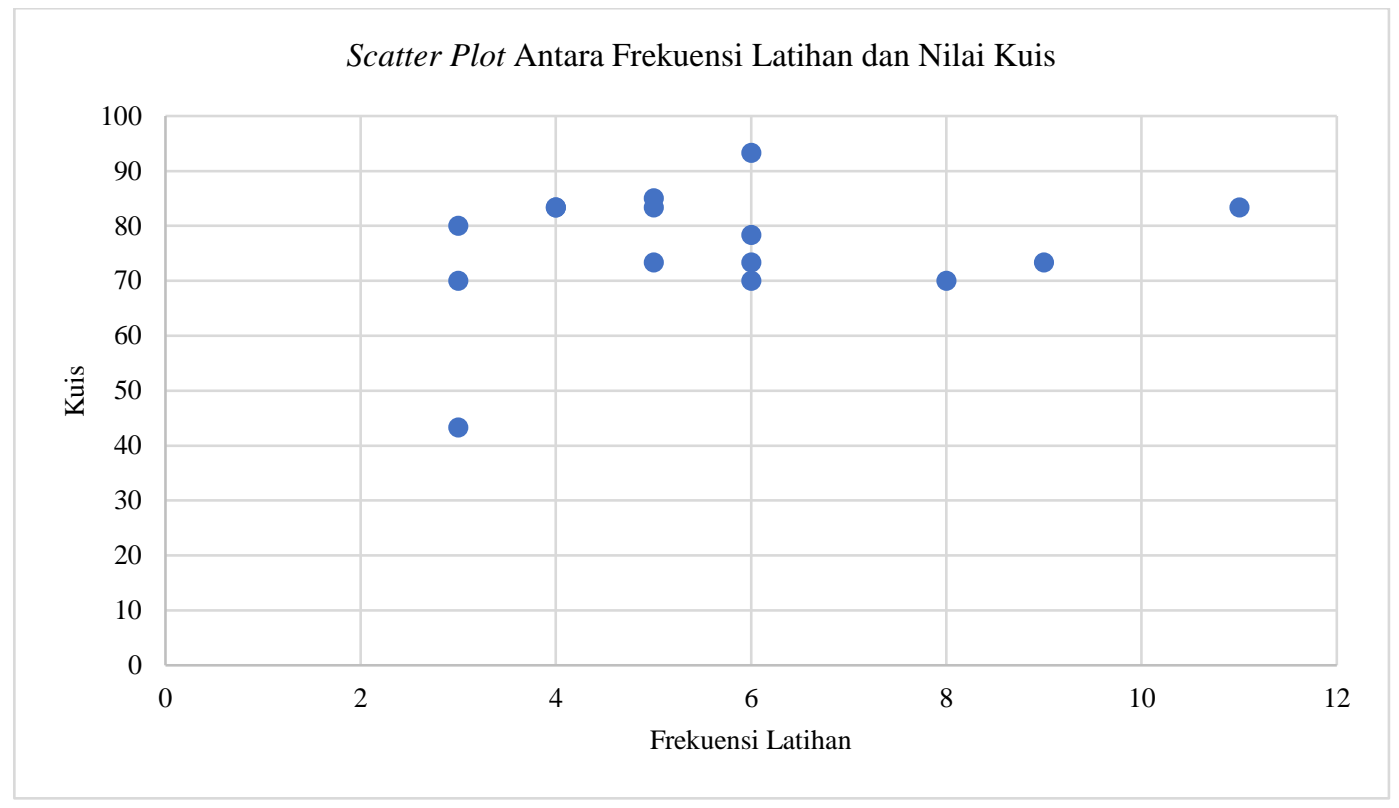

Gambar 13. Diagram Scatter Plot Antara Frekuensi Latihan dan Nilai Kuis

Berdasarkan diagram scatter plot di atas, rata-rata frekuensi latihan yang dilakukan anak-anak adalah 5.6 kali dengan 46.67\% anak-anak yang memiliki frekuensi latihan di atas rata-rata. Rata-rata nilai kuis anak-anak yang memiliki frekuensi latihan di atas rata-rata adalah $77.38 \%$, sedangkan rata-rata nilai kuis anak-anak yang memiliki frekuensi latihan di bawah rata-rata adalah $75.21 \%$. Kemudian, dilakukan perhitungan koefisien korelasi menggunakan formula CORREL yang ada di dalam Excel untuk mengetahui apakah ada korelasi antara variabel nilai kuis dan variabel total frekuensi latihan. Nilai $|r|$ dari hasil perhitungan adalah 0.2162 . Hal tersebut menunjukkan bahwa nilai $|r|<0.3$ yang mengindikasikan korelasi bersifat lemah atau hampir tidak ada korelasi antara frekuensi latihan yang dilakukan anak-anak dengan hasil kuis yang didapatkan.

6) Hasil Evaluasi Pengujian:Tabel 6 dan Tabel 7 merepresentasikan hasil kuesioner yang melibatkan lima belas anak kelas empat SD.

TABEL 6

Hasil Kuesioner Pengujian APLiKasi

\begin{tabular}{llcc}
\hline ID & \multicolumn{1}{c}{ Penyataan } & $\begin{array}{c}\text { Rata- } \\
\text { Rata }\end{array}$ & $\begin{array}{c}\text { Standar } \\
\text { Deviasi }\end{array}$ \\
\hline Q1 & $\begin{array}{l}\text { Aplikasi pembelajaran "Smart Learning with Moodle" ini mudah untuk saya gunakan. Mulai dari } \\
\text { saya login sampai mengerjakan latihan soal. }\end{array}$ & 3.800 & 0.414 \\
\hline Q2 & Saya mudah memahami penjelasan materi yang ada di dalam aplikasi. & 3.467 & 0.640 \\
\hline
\end{tabular}




\begin{tabular}{llcc}
\hline ID & \multicolumn{1}{c}{ Penyataan } & $\begin{array}{c}\text { Rata- } \\
\text { Rata }\end{array}$ & $\begin{array}{c}\text { Standar } \\
\text { Deviasi }\end{array}$ \\
\hline Q3 & $\begin{array}{l}\text { Gambar-gambar yang digunakan di dalam aplikasi untuk menjelaskan materi membantu saya } \\
\text { untuk mengerti. }\end{array}$ & 3.800 & 0.414 \\
\hline Q4 & $\begin{array}{l}\text { Suara-suara yang digunakan di dalam aplikasi saat menjawab soal membuat aplikasinya lebih } \\
\text { menarik. }\end{array}$ & 3.733 & 0.458 \\
\hline Q5 & $\begin{array}{l}\text { Saya merasa latihan-latihan soal di dalam aplikasi yang diberikan setiap selesai pembahasan materi } \\
\text { menarik untuk saya kerjakan. }\end{array}$ & 3.667 & 0.488 \\
\hline Q6 & $\begin{array}{l}\text { Saya merasa latihan-latihan soal di dalam aplikasi yang diberikan setiap pembahasan materi sesuai } \\
\text { dengan materi yang dijelaskan. }\end{array}$ & 3.800 & 0.414 \\
\hline Q7 & Aplikasi pembelajaran ini dapat membantu saya dalam belajar Pecahan. & 3.867 & 0.352 \\
\hline
\end{tabular}

Pada pernyataan kuesioner Tabel 6, empat skala perbandingan yang digunakan adalah Tidak Setuju bernilai 1, Kurang Setuju bernilai 2, Setuju bernilai 3, dan Sangat Setuju bernilai 4. Berdasarkan Tabel 6, nilai rata-rata tertinggi antara pernyataan dengan ID Q1 dan Q7 diperoleh pernyataan dengan ID Q7. Hal ini terjadi mungkin dikarenakan penggunaan alat bantu seperti komputer yang dinilai sangat menarik oleh anak-anak SD. Pernyataan dengan ID Q7 memiliki standar deviasi yang paling rendah, yang berarti banyak yang sangat setuju dengan pernyataan tersebut. Menurut anak-anak yang mencoba aplikasi pembelajaran tersebut, aplikasi ini dapat membantu mereka dalam mempelajari materi yang diujikan, yaitu materi Pecahan.

Untuk nilai rata-rata terendah antara pernyataan dengan ID Q1 dan Q7 diperoleh pernyataan dengan ID Q2. Meskipun memperoleh nilai rata-rata terendah, nilai rata-rata dari pernyataan dengan ID Q2 (3.467) masih berada di atas nilai tengah skala perbandingan kuesioner (2.500). Standar deviasi dari pernyataan dengan ID Q2 juga masih tergolong kecil, yaitu 0.640. Oleh karena itu, mayoritas anak-anak masih cenderung mudah memahami penjelasan materi yang ada di dalam aplikasi. Meskipun begitu, penjelasan materi akan lebih diperhatikan lagi agar semakin mempermudah pemahaman anak-anak.

TABEL 7

HASIL KUESIONER PENGUJIAN SOAL

\begin{tabular}{|c|c|c|c|}
\hline ID & Pernyataan & $\begin{array}{c}\text { Rata- } \\
\text { Rata }\end{array}$ & $\begin{array}{l}\text { Standar } \\
\text { Deviasi }\end{array}$ \\
\hline Q8 & Saya merasa soal-soal latihan pada Bab 1.1 “Apa itu Pecahan?” itu... & 3.467 & 0.640 \\
\hline Q9 & Saya merasa soal-soal latihan pada Bab 1.2 "Letak Pecahan dalam Garis Bilangan” itu... & 3.667 & 0.617 \\
\hline Q10 & Saya merasa soal-soal latihan pada Bab 2.1 "Pecahan Senilai" itu... & 3.067 & 0.884 \\
\hline Q11 & Saya merasa soal-soal latihan pada Bab 2.2 "Menyederhanakan Pecahan" itu... & 3.067 & 0.884 \\
\hline Q12 & Saya merasa soal-soal latihan pada Bab 3 "Perbandingan Pecahan" itu... & 3.733 & 0.458 \\
\hline
\end{tabular}

Untuk pernyataan kuesioner Tabel 7, empat skala perbandingan yang digunakan adalah Sangat Sulit bernilai 1, Sulit bernilai 2, Mudah bernilai 3, dan Sangat Mudah bernilai 4. Untuk pernyataan dengan ID Q8 sampai dengan Q12 yang membahas tentang tingkat kesulitan soal-soal latihan yang terdapat di dalam materi dan berdasarkan Tabel 7, nilai rata-rata tertinggi diperoleh pernyataan dengan ID Q12. Hal ini terjadi mungkin karena jumlah soal latihan yang terdapat pada Bab 3 "Perbandingan Pecahan" hanya sedikit (dua soal) dibandingkan dengan jumlah soal latihan yang terdapat pada bab yang lain. Selain itu, tingkat kesulitan soal latihan pada bab tersebut masih tergolong mudah. Standar deviasi dari pernyataan dengan ID Q12 adalah 0.458, yang berarti mayoritas anak-anak masih sangat setuju dengan pernyataan tersebut.

Perolehan nilai rata-rata terendah antara pernyataan dengan ID Q8 sampai dengan ID Q12 adalah pernyataan dengan ID Q10 dan ID Q11, yaitu sama-sama bernilai 3.067. Hal ini terjadi mungkin dikarenakan jumlah soal latihan yang banyak dengan beberapa soal yang menuntut lebih dari satu jawaban dan menyulitkan anak-anak dalam mengerjakan soal latihan tersebut. Meski memperoleh nilai rata-rata terendah, pernyataan dengan ID Q10 dan ID Q11 masih berada di atas nilai tengah skala perbandingan kuesioner. Standar deviasi yang dimiliki juga masih tergolong kecil, yaitu 0.884. Meski begitu, dalam proses pembuatan soal kedepannya akan lebih diperhatikan lagi tingkat kesulitan masing-masing soal.

\section{SIMPULAN}

Aplikasi yang menggunakan platform LMS Moodle telah berhasil diterapkan dengan materi mata pelajaran matematika sebagai materi pembelajaran. Setelah itu, pengujian aplikasi ini telah dilakukan terhadap 15 anak-anak kelas 4 SD. Berdasarkan evaluasi yang telah dilakukan, hasil data analisis pengujian T-Test yang membandingkan nilai tes tertulis dengan nilai kuis aplikasi menunjukkan perbedaan yang tidak signifikan, namun hasil analisis yang didapatkan menunjukkan peningkatan rata-rata nilai, nilai tertinggi, dan nilai terendah, serta penurunan standar deviasi. Selain itu, berdasarkan hasil perhitungan koefisien korelasi pada diagram scatter plot, nilai $|r|=0.2162$ menunjukkan korelasi lemah atau hampir tidak 
korelasi antara frekuensi latihan yang dilakukan anak-anak dengan hasil kuis. Berdasarkan hasil kuesioner, aplikasi ini dinilai membantu anak-anak memahami materi Pecahan. Saran yang dapat diberikan adalah penambahan materi untuk pengujian, hasil analisis data dan penarikan kesimpulan dapat lebih valid. Pengujian juga dapat dilakukan dengan dua kelompok subjek yang berbeda, agar dapat dianalisis pengaruh antara kelompok subjek yang menggunakan aplikasi dan yang tidak menggunakan aplikasi.

\section{DAFTAR PUSTAKA}

[1] “Kementrian Pendidikan dan Kebudayaan,” [Online]. Available: https://ubk.kemdikbud.go.id/. [Diakses 18 November 2017].

[2] T. J. McGill dan J. E. Klobas, “A task-technology fit view of learning management system impact,” Computers \& Education, vol. 52, no. 2, pp. 496$508,2009$.

[3] Indriani, R., \& Nodia, F. (2017, December 12). Profesor Ini Ungkap Mengapa Matematika Dianggap Sulit. Retrieved from Suara.Com: https://www.suara.com/tekno/2016/10/05/110207/profesor-ini-ungkap-mengapa-matematika-dianggap-sulit

[4] W. R. Watson dan S. L. Watson, "An Argument for Clarity: What are Learning Management Systems, What are They Not, and What Should They Become?," TechTrends, vol. 51, no. 2, pp. 28-34, 2007.

[5] B. Courts dan J. Tucker, "Using Technology To Create A Dynamic Classroom Experience,” Journal of College Teaching \& Learning (Online), vol. IX, no. 2, p. 121, 2012.

[6] E. Sutanta, "Konsep dan Implementasi E-Learning," IST AKPRIND Yogyakarta, 2009.

[7] B. Gold dan R. A. Simons, Proof and Other Dilemmas: Mathematics and Philosophy, Washington: The Mathematical Association of America, 2008.

[8] "Khan Academy," 2017. [Online]. Available: https://www.khanacademy.org/math/cc-fourth-grade-math. [Diakses 8 December 2017].

[9] J. Cole dan H. Foster, "Using Moodle: Teaching with the popular open source course management system", Sebastopol: O'Reilly, 2007.

[10] S. Graf dan B. List, “An Evaluation of Open Source E-Learning Platforms Stressing,” IEEE Xplore, no. 5, 2005

[11] "Khan Academy," 2008. [Online]. Available: https://www.khanacademy.org/about. [Diakses 11 April 2017].

[12] J. Hohenwarter, M. Hohenwarter dan Z. Lavicza, "Introducing Dynamic Mathematics Software to Secondary School Teachers: The Case of GeoGebra," Journal of Computers in Mathematics and Science Teaching, vol. 28, no. 2, pp. 135-146, 2009.

[13] V. Dagiene dan G. Stupuriene, "Bebras - a Sustainable Community Building Model for the Concept Based Learning of Informatics and Computational Thinking," Informatics in Education, vol. 15, no. 1, pp. 25-44, 2016.

[14] V. Dagiene dan S. Sentance, "It's Computational Thinking! Bebras tasks in the curriculum," ISSEP 2016: Informatics in Schools: Improvement of Informatics Knowledge and Perception, vol. 9973, pp. 28-39, 2016.

[15] A. W. Gunawan, Genius Learning Strategy, Jakarta: PT Gramedia Pustaka Utama, 2012. 